\title{
RFP -575
}

\section{BRIEF REVIEW OF THE INIDTRNATIONAL SYMPOSIUM}

HEIN IN ATBUQULRQUE, NEW MEXICO

R. I. Delnay

April 5, 1965

\section{THE DOW CHEMICAT COMPANY \\ Rocky Flats Division \\ Golden, Colorado}

LEAL NOTICE- Nether the United This report wan prepared as an account of Government sponsored workm Nasedion:

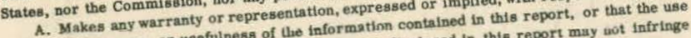
A. Mompleteness, or usefulness of the informatinn contiod in this report may wot of any information, apparatus, method, or process das for damages resulting from the privately owned rights; or

B. Any information, apparatus, method, or procels of the Commission" includes any em-

As uned in the above, "Dermisulon, or omplinyee of such contractor contractor propares. ployee or contractor of such employeo or provides access to, any informatlon purator.

disseming

U.S. Atomic Enerey Commission Contract AT(29-1)-1106 


\section{DISCLAIMER}

This report was prepared as an account of work sponsored by an agency of the United States Government. Neither the United States Government nor any agency Thereof, nor any of their employees, makes any warranty, express or implied, or assumes any legal liability or responsibility for the accuracy, completeness, or usefulness of any information, apparatus, product, or process disclosed, or represents that its use would not infringe privately owned rights. Reference herein to any specific commercial product, process, or service by trade name, trademark, manufacturer, or otherwise does not necessarily constitute or imply its endorsement, recommendation, or favoring by the United States Government or any agency thereof. The views and opinions of authors expressed herein do not necessarily state or reflect those of the United States Government or any agency thereof. 


\section{DISCLAIMER}

Portions of this document may be illegible in electronic image products. Images are produced from the best available original document. 
I have been asked to review the Symposium on Packaging and Transportation of. Radioactive Materials which was held in Albuquerque this past January. ThIs request presents quite a challenge. As a subcommittee chairman for the Institute, I am happy to say that great strides have been made toward compatible shipping regulations for fissile materiel. Also, a good deal of work has been done to show the Integrity of shipping packages.

Before we start, it might be of interest to know that there were approximately 260 people representine 8 different countries.

The meeting divides nicely into four maln areas:

1. comments on regulations;

2. structural integrity tests of packages used prior to regulations 10CFR71 and 0529;

3. packages designed to meet 10CFR71 and 0529; and

4. observation of a fire and drop test.

Rather than abstract each paper as an individual entity, I'II try to present the high-lights.

\section{Comments on Regulations}

The most important phase of the packaging and transporting of radioactive materials is the governing regulations. This importance was emphasized when it wus pointed out that IAFA regulations and our regulations should be compatible. Incompatible regulations would result in mass confusion, needless delays, and high transportation costs. 
Presently in this country we have two sets of regulations for fissile materials, one for AEC and its contractors, and another for licensees. Contractor regulations are published as AEC Manual Chapter 0529, dated May 21, 1964. The code of Federal Regulations, Section 10, Part 71, detalls the proposed regulation as applied to licensees: The latest revision of the proposed regulation was distributed for discussion on November 6, 1964. I'll simply refer to the regulations as "0529" and "10CFR7I" respectively during the remainder of this review.

Both the contractors' regulations and the proposed licensees' regulations recognize three classes of shipments for fissile material: Class I, Class II, and Class III.

Class I requires that the package be designed and fabricated so that an infinite number of any Class I undamaged packages will be sub-critical in any arrangement. Two hundred and fifty similar packages after accident test conditions are sub-critical in any arrangement. As a result, these packages require no control during transport by either the shipper or carrier.

Class II requires that the package be designed and fabricated so that a finite number of any Class II undamaged packages will be sub-critical in any arrangement. After accident test conditions, twice that number of similar damaged packages will be nuclearly safe in any arrangement. These packages require no control by the shipper during transport. The carrier must prevent the accumulation of packages whlch would total more than 40 "radiation units." 
Class III requires administrative control by the shipper to insure nuclear safety. An excellent example of administrative control is described in a portion of a paper presented at the Symposium. This paper detailed the. controls exercised by a shipper in moving a large quantity of americium solution from Savannah River to Oak Ridge: A "dry run" occurred approximately one month prior to the shipment. This allowed the shipper to check train schedules, track and siding conditions, handling details, and road conditions of the truck route from the rail head to the plant.

The regulations detail tests which determine the structural integrity of the packages. Without detailing each test in each regulation, it's sufficient to say that differences do exist. Essentially, the package must maintain its structural integrity through tests which represent normal transport conditions and a set of accident test conditions.

The tests which represent normal transport conditions include:

1. free fall of the package onto a flat, unyielding surface;

2. a penetration by a I-1/4 inch steel cylinder dropped from four feet;

3. a 30-minute water spray; and

4. a 24-hour compression test w1th a load equivalent to five times package weight. 
TABLE I

Normal Transport Test Conditions

0529

$4 \mathrm{ft}$

Impact

Penetration

(1-1/4 in)

Wáter Spray

$(30 \min )$

Compression

(24 hrs)
12 Ibs

$1 \mathrm{gpm}$

$5 \mathrm{X}$
10CFR71

$4 \mathrm{ft} ;<10,0002 \mathrm{bs}$

$3 \mathrm{ft} ; 10,000-20,000$

2 ft; 20,000-30,000 !!!

I ft; > 30,000

13 Ibs

$5 x$ 
Reguiation 0529 specifies a 12-pound bar and a spray of not less than one galion per minute for the penetration and water spray tests respectively, whereas IOCFR71 requires a 13-pound rod and a spray of not less than four gallons per minute for the respect1ve tests. The free fall in 10CFR71 varies from one to four feet, depending upon total weight of the package; and 0529 specifies a four-foot drop.

A sequence of four tests determines the structural integrity of packages for transport accident conditions: "

1. A 30-foot free fall of the package onto a flat, unyielding surfaces

2. A fall of 40 inches onto a piston 6 inches in diameter;

3. A fire test; and

4. A water immersion test for 24 hours to a depth of 3 feet. 
$-6-$

TABLE II

Accident Test Conditions

Impact

Puncture $(6 \mathrm{in})$ $\underline{0529}$

$30 \mathrm{ft}$

8 in

$60 \mathrm{~min}$

Water Immersion
$(3 \mathrm{ft})$

$24 \mathrm{hrs}$
Fire
10CFR71

$30 \mathrm{ft}$

Sufficient length

$30 \min$

$24 \mathrm{hrs}$

!! ! 
Regulation 0529 specifies a plston elght inches high; and 10CFR71 requires the piston to be of sufficient length to cause maximum damage to the package, or not less than eight inches high. The fire test in 0529 involves the first hour of the standard time-temperature curve. 10CFR71 requires exposure for 30 minutes to a specified thermal environment.

The criticality evaluations for a single damaged package differ in that IOCFRTI assumes that water leaks into or liquid leaks out of the containment vessel, regardless of the observations made during the accident test conditions. 0529 does not contain this assumption.

Those items just mentioned represent the main differences. Now I would like to quote remarks 2 and 3 from the transmittal notice on 0529, since these two emphasize the importance of uniformity of regulations.

"2. The U.S. Coast Guard has established regulations which require the AEC to approve procedures for shipping fissile materials, and the Interstate Commerce Commission (ICC) has proposed taking essentially similar action. Appendix 0529, part I, establishes the standards which the AEC shall apply to its operations in carrying out its responsibility. This appendix shall now be used in its entirety for shipments which are under Coast Guard cognizance. Shipments made by other modes of transport shall use only Class I and Class III criteria until such time as the ICC and Federal Aviation Agency (FAA) promulgate regulations which will establish fissile material labeling requirements permitting the use of the "40 unit" rule. At that time cliass II shall become effective. 
"3. In order to be assured that all shippers act in a consistent manner, it is considered desirable that the technical standards contained in the chapter be essentially identical to those in the AEC regulations. The appropriate $\mathrm{HQ}$ staffs have been working to achieve this objective, and it is believed that substantial agreement has been reached. After considering appropriate comments from interested parties, including AEC operations staffs and contractors, a final version of the comparable AEC regulations. ( $10 \mathrm{CFR}$ part 71 ) will be submitted to the Commission for consideration. Following Commission approval, it may be necessary to make revisions in the chapter.".

Since neither the ICC nor the FAA has established regulations for the transport of fissile materials yet, one paper showed how a contractor ships Class II by common carrier in lieu of these regulations.

One of the more thought-provoking papers concerned toll bxidges, tunnels, and turnpikes. The speaker claimed "luck" has played a major role in the past to impart our near accident-free record. Briefly, the paper concerned money. Who would pay for replacing or decontaminating a toll facility? Who would replace the lost revenues; and how long would a facility be out of service? These three questions are of a major importance to toll authorities. Until someone can supply these answers, shipments of fissile material will not use toli facilities.

Three papers presented data and oplnions on flre tests. One paper detailed the optimum surface area and volume of a pool of fuel for an open pit fire 
test. These three papers failed to establish that fire tests can be performed on scaled models. The economic advantages of using models are obvious.

One paper definitely pointed out that presently scaled models could not be, used for the impact tests.

\section{Structural Intcgrity Tests on Packages Used Prior to Regulations}

Nine papers with appropriate slides or movies demonstrated the ability of existing packages to pass the structural integrity tests. One very obvious conclusion is that packages were built stout. Those papers which dealt with small packages indicated that the standard 55-gallon drum furnishes an economical, readily available, and satisfactory outer container.

All of these packages were tested prior to the latest revision of 10CFR71. In ali probability, the 10-ton capacity, uranium hexafluoride packages will not survive the puncture test as described in the November 6, 1964, revision. If you will recall, this puncture test calls for the six-inch piston to be of such height to cause maximum damage to the package. High speed film of the test showed that the piston caved in the package wall considerably. The thin-walled package did not rupture. However, the piston was only eight inches high, which allowed the ends of this huge cylinder to come to rest on the steel plate (flat, unyielding surface). It is not too' difficult to conceive that a longer platon might mupture this package.

Another paper described the work Involved in establishing the gage, width,

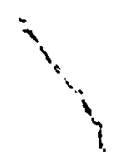


number, and arrangement of steel bands around a wood box to prevent 2085 of material. The movie showed on the first series of drops that most of the damage to the package occurred when the ball and hook of the crane hit the box.

In general, the other papers showed that individual's have their own opinions as to what constitutes maximum damage to a package on the 30-foot free fall. As an example, most of those people concerned with nuclear safety believe that a flat drop is most damaging, since a greater reduction in volume of the package results. Others figure a drop which might shear off valves, bolts, etc., are the most damaging, since this is more likely to cause loss of containment.

Packages Designed to Meet the Regulations

Of the group of papers which described packages designed to meet the regulations, one paper describes a set of packages which is easily assembled for a specific shipment. Briefly, the package consists of concentric cylinders which provide additional thermal insulation and gamma shielding. This appears to be a practical approach to provide packages for varying amounts of a radio isotope such as cobalt 60 up to 20,000 curies.

The remaining papers described the design, testing, and nuclear considerations of packages 'designed for specific materials.

We also heard a plea to standardize on the packages arready assigned B of $E$ 
permits, or to establish a standard package which one might be able to buy. as an "off-the-shelf" item.

\section{Observation of a Fire and Drop Test}

The demonstration fire and drop test occurred on Tuesday morning. Jim Sisler deserves a lot of credit for scheduling the drop and fire tests as he did. First, he picked the only morning without wind. Also, he chose the coldest morning, so we (the visitors) could enjoy the bonfire. It just happened that this A.M. was also the morning-after-the-night-before; Monday evening was banquet night.

The open pit fire test on the three packages demonstrated to the non-believers that wood provides excellent thermal insulation. The condition of DuPont's package after the test impressed people with the force (energy, if you wish) possessed by molten lead. Unfortunately, only the United Kingdom's package was disassembled after the fire teat. It was readily apparent that the integrity of the package remained, since the wood was charred to a depth of only $1-1 / 2$ to 2 inches.

The drop tower at Sandia is so constructed that the specimen is suspended from a cable which muns diagonally from the top of the tower to a concrete abutment. This allows the specimen to drop with a horizontal velocity in addition to a vertical velocity if one so desires. A tro-ton; wood-insulated cask was dropped 30 feet onto a corner. The wood consisted of laminated fir plywood. Observation after the drop showed shearing of the wood. This shearing did not 
happen on the first test, the difference being that nails were used in addition to Elmer's Glue to fasten the layers of plywood. Since the package was to be fire-tested next, the wood overcoat, as Sandia cails. 1t, was not removed to observe the condition of the cask. I feel quite confident that the Symposium . proceedings will show that the cask survived the fire test.

\section{5-Galion Drum Size Shipping Packages}

I have picked a few slides to show structural integrity test, the results of these tests, and the construction of typical 55-galion drum size shipping packages.

Slide 1 shows the construction details of a Class.I package. This package will hold approximately three liters of solution. As you can see, the outer container is a standard ICC 17C open top, 55-gallon drum, with a 12-gauge bolt type locking ring. The drum Ild is vented to allow equalization of pressure during shipment and to provide a vent for gases if the package is exposed to a fire. A white-oak lamination surrounds the pressure vessel. The oak furnishes neutron moderation, thermal Insulation, and mechanical strength. A polyethylene bottle which fits inside the pressure vessel contains the solution to be shipped.

(Slide 2) The next slide shows the same inner container supported in a birdcage framework and surrounded with Vermiculite for thermal insulation. This is considered a Class II package. 
Slide 3 shows the damage to the bolt ring portion of a Class I package after a 30-foot drop onto the bolt ring. Prior to the fire test, the package was opened to install thermocouples. As this next slide (slide 4) shows, only slight deformation occurred. The next slide (slide 5) 11lustrates the strength of wood, since the bolts failed to bend.

The fire test was conducted as described by National Fire Protection Association Test Number 251. In this particular test, the package remained in the hot furnace with the power off an additional 45 minutes before it could be removed. Slide 6 shows the temperatures at fixed points before, during, and after the test. Thermocouple locations are designated in inches from the outside surface of the wood. The charring across the wood top is shown in the next slide (Slide 7). Slide 8 is the under side of the same top. The depth of char; approximately 1-1/4 Inches, occurred around the periphery of the lower base lamination (Slide 9).

A 12-pound, 1-1/4 inch steel bar used in the penetration tests is ready for release (Slide 10). The next slide (Slide 11) shows the bar a moment after impact. To date, and to the best of my knowledge, no 12. or 13-pound steel rod has, ever penetrated the skin of a standard ICC drum.

A compression test for a Class I package required 5250 pounds for 24 hours. That amount of weight is shown on the package approximately 20 hours after the test started (slide 12). 
Slide 13 is an excelient view of the strength, possessed by a drum and a 12gauge locking type bolt ring. Although the wood shows, it required crow bars, hammers, two men and a boy to remove the bolt ring and drum lid.

As you would expect, more deformation of the drum occurs during the impact tests on Class II packages. In fact, the next three slides will show the fallure of a birdcage to keep a pressure vessel centered within the drum after a 30-foot drop. Slide 14 shows the damage to the drum and the top of the pressure vessel against the drum skin. The birdcage and pressure vessel are shown in the next slide (slide 15). A close-up of the broken weld and the bent steel tubing are show in slide 16.

The next slide (Slide 17) shows a Class II package after being dropped from 30 feet and impacting on its aide. Slide 18 shows the damage to the upper portions of the drum after three 30-foot drops (upright, flat, and corner). A view of the pressure vessel lid and its position with respect to the dmum is shown in slide 19.

The last series of slides illustrates the condition of a package which was fabricated by welding two standard drums together end to. end. Slide 20 shows the bar ready for the second penetration test. You can see the dent in the drum lid caused by the rod on the first test. The package on the first bounce is shown in Sizde 21. Notice the Impression left by the top of the birdcage. Slide 22 is a close-up of the drum IId and shows the outline of the birdcage quite well. The moment of inpact during the puncture test 18. shown in slide 23. 
The last slide (Slide 24) shows the position of the pressure vessel in the drum.

In summary, I would like to say that the Symposium was well attended, offered a free exchange of information, provided excellent personal contacts, and showed that a tremendous amount of effort has alreddy been expended to provide for the safe transport of fissile materials. 